\title{
Two Cases of Fungus Ball in Bilateral Paranasal Sinuses
}

\author{
Hyun-Sang Cho, Kyu-Eun Lee and Kyung-Soo Kim \\ Department of Otorhinolaryngology-Head and Neck Surgery, College of Medicine, Chung-Ang University, Seoul, Korea
}

\section{양측 부비동에서 발생한 진균구 2 예}

조현상 · 이규은 · 김경수

중앙대학교 의과대학 이비인후-두경부외과학교실

\author{
Received February 27, 2013 \\ Revised July 25, 2013 \\ Accepted July 30, 2013 \\ Address for correspondence \\ Kyung-Soo Kim, MD, PhD \\ Department of Otorhinolaryngology- \\ Head and Neck Surgery, \\ College of Medicine, \\ Chung-Ang University, \\ 102 Heukseok-ro, Dongjak-gu, \\ Seoul 156-755, Korea \\ Tel $+82-2-6299-1777$ \\ Fax $+82-2-825-1765$ \\ E-mail 99-21045@hanmail.net
}

Fungus ball of the paranasal sinuses is usually found in only one sinus, most frequently in the maxillary sinus. It may produce symptoms of chronic rhinosinusitis, such as purulent rhinorrhea, nasal obstruction, headaches, and sensation of pressure. However, cases involving bilateral paranasal sinuses are rarely reported. Herein we report two cases of fungus ball in bilateral paranasal sinuses with a review of this disease entity.

Korean J Otorhinolaryngol-Head Neck Surg 2014;57(3):185-9

Key Words Bilateral paranasal sinuses $\cdot$ Fungi $\cdot$ Sinusitis.

\section{서 론}

진균성 부비동염은 크게 비침습성과 침습성으로 나눌 수 있다. 진균구는 가장 흔히 볼 수 있는 비침습형 진균성 부비동 염으로, 성인에서 주로 발생하며 일반적인 치료에 잘 반응하 지 않는 만성 부비동염의 형태로 면역기능이 정상인 환자에서 주로 나타난다.

진균구는 대개 편측성으로 하나의 부비동에 주로 침범하 며, 대부분 상악동을 침범한다.1) 진균구가 여러 부비동을 침범 하는 다발성인 경우가 $6.4 \%$ 로 보고되고 있고, 다발성으로 발 견되더라도 진균구에 의해 침범된 부비동들은 거의 대부분 편 측성으로 인접해 있다.1) 진균구가 양측 부비동을 침범하는 경 우는 1.25 3.4\% 정도로 드물게 보고되고 있다. ${ }^{1-4)}$

따라서, 양측성 부비동 진균구는 보편적이지 않고 그 특징 에 대해 상세하게 기술되어 있지 않아 최근 저자들이 치험한 양측 부비동에 발생한 진균구 2예에 대해 문헌고찰과 함께 보고하는 바이다.

\section{증 례}

\section{증 례 1}

33세 여자 환자가 5년 전부터 간헐적으로 나타나는 두통 및 콧물을 주소로 본과에 내원하였다. 상기도감염 증상이 있을 시 심해지는 코막힘을 동반하는 두통과 콧물로 이비인후과 병 원에서 약물치료로 증상의 호전과 악화가 반복되었다. 환자는 내원 9년 전부터 갑상선기능저하증으로 갑상선호르몬(Synthyroid $^{\circledR}$, Abbott Laboratories, North Chicago, IL, USA)을 복 용 중인 것 외에는 특이사항은 없었다. 비강 내시경검사에서 비 중격 만곡은 없었고, 비강용종도 관찰되지 않았다. 부비동 컴 퓨터단층촬영에서 양측 상악동에 석회화를 포함한 혼탁음영 이 있었다. 상악동 벽의 골경화 소견이 관찰되었으나 골미란은 관찰되지 않았다(Fig. 1). 양측 상악동에 진균구로 추정진단을 내리고 양측 부비동 내시경수술을 시행하였다. 양측 상악동내 에 흑갈색 덩어리의 진균구가 발견되었으며 다양한 겸자와 굽 은 흡입기를 이용하여 제거하였고, 잔존의 흑갈색 덩어리를 제 거하기 위해 수회의 식염수 세척을 시행하였으며, 양측 상악동 
의 입구부를 크게 열어준 뒤 수술을 마쳤다. 수술 후 2일째 팩 킹을 제거하고 별다른 문제없이 퇴원하였고 이후 양측 진균구 는 조직검사 상 모두 국균(aspergillosis)으로 확진되었다(Fig. 2). 환자는 퇴원 후 12 개월 동안 비강 내시경을 통한 추적관찰 에서 재발 등의 특이소견은 보이지 않았다.

\section{증 례 2}

72세 여자 환자가 내원 6개월 전부터 시작된 심한 악취 및 두 통을 주소로 외부 이비인후과에서 약물치료 하였으나 증상이 지속되어 본원 이비인후과로 내원하였다. 현 병력상 8년 전부 터 고혈압으로 약물복용 중인 것 이외에는 특이사항 없었다. 비강 내시경검사에서 좌측으로의 비중격만곡증 소견이 관찰 되었고, 우측 중비도에 화농성 비루 소견을 보였다. 부비동 컴 퓨터단층촬영에서 우측 상악동과 좌측 접형동의 골벽비대와 고음영의 구성성분을 포함하는 부비동염 소견이 관찰되었고, 우측 사골동에도 부비동염 소견이 관찰되었다(Fig. 3). 양측 부 비동(우측 상악동, 좌측 접형동)의 병변을 진균구로 추정진단 내리고 양측 부비동 내시경 수술을 시행하였다. 우측 상악동 내에 흑갈색 덩어리는 다양한 겸자와 굽은 흡입기를 이용하여
제거하였고, 잔존의 흑갈색 덩어리를 제거하기 위해 수회의 식 염수 세척을 시행하였으며, 동반된 사골동의 염증을 제거하였 다. 좌측은 접형동 입구부를 확장해서 접형동의 전벽을 제거 한 후 흑갈색 덩어리의 진균구가 관찰되어 우측 상악동과 같 은 방법으로 완전 제거 후 수술을 마쳤다. 수술 후 2일째 팩킹 을 제거하고 별다른 문제없이 퇴원하였고, 수술 중 제거한 표 본의 조직검사 결과 양측 진균구는 모두 국균(aspergillosis) 으로 확진되었다(Fig. 4). 환자는 퇴원 후 12개월 동안 비강 내 시경을 통한 추적관찰에서 재발 등의 특이소견은 보이지 않 았다.

\section{고 찰}

진균구를 포함한 진균성 부비동염은 비교적 드문 질환으로 알려져 왔으나 최근 발병 빈도가 증가하고 있는 추세이다. 이 는 광범위 항생제의 남용, 면역기능이 저하된 환자의 증가, 컴 퓨터단층촬영, 자기공명영상 및 진균배양과 분자생물학적 진 단법 등의 진단기술 발전에 기인한다. ${ }^{5}$ 과거와 달리 면역기능 이 저하된 환자가 증가하는 이유는 악성종양이나 장기이식 환
Fig. 1. Preoperative CT scans. Axial image $(A)$ and coronal image $(B)$ show microcalcifications, soft tissue density and bony sinus wall thickening in bilateral maxillary sinuses.
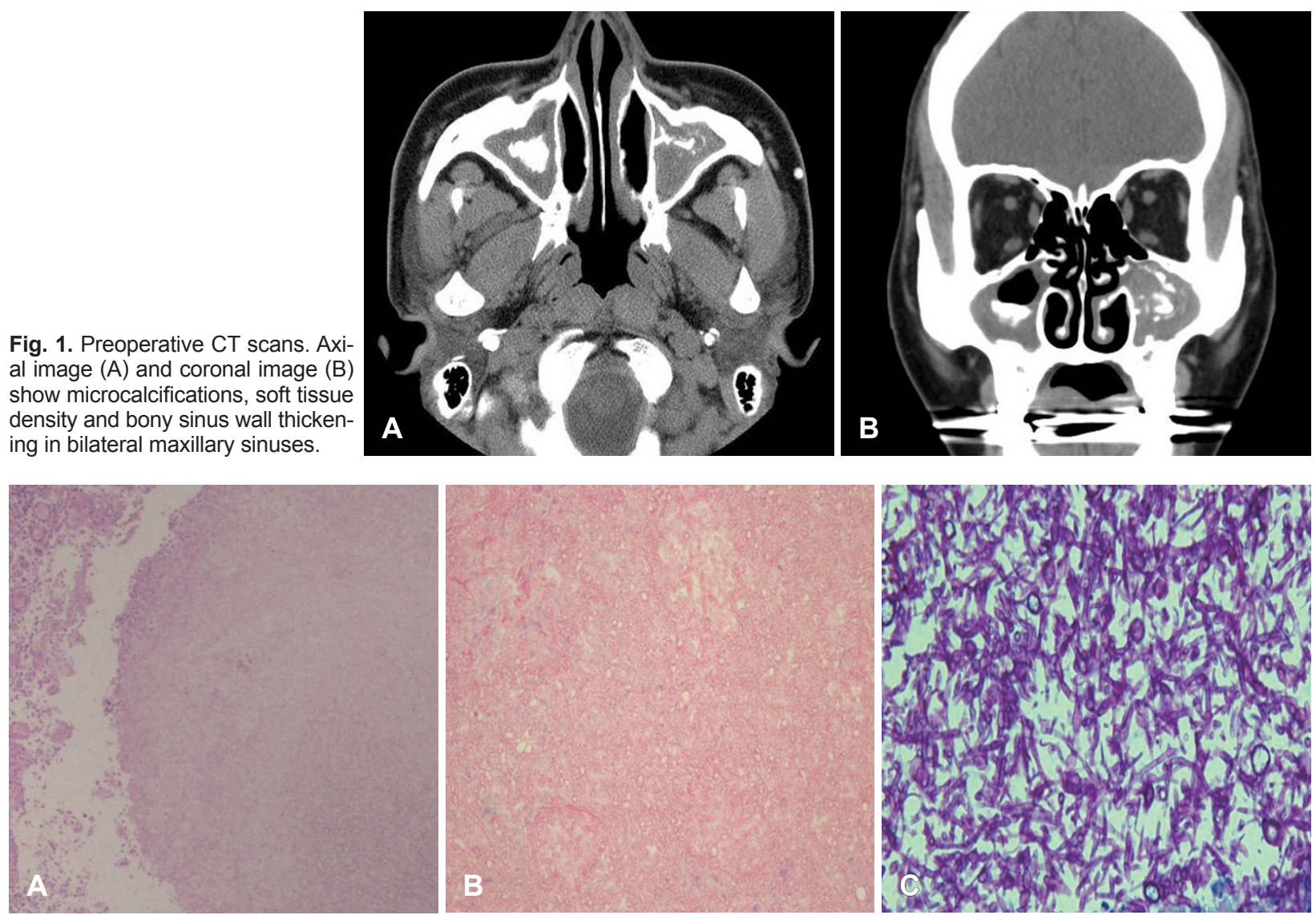

Fig. 2. Fungus ball composed of numerous fungal hyphae was observed in right maxillary sinus (H\&E stain, $\times 40)(A)$ and left maxillary sinus $(H \& E$ stain, $\times 100)(B)$. The fungal hyphae show septate filaments, regular thick, branching at acute angle. These morphologic findings are consistent with Aspergillus (PAS stain, $\times 200)(C)$. 

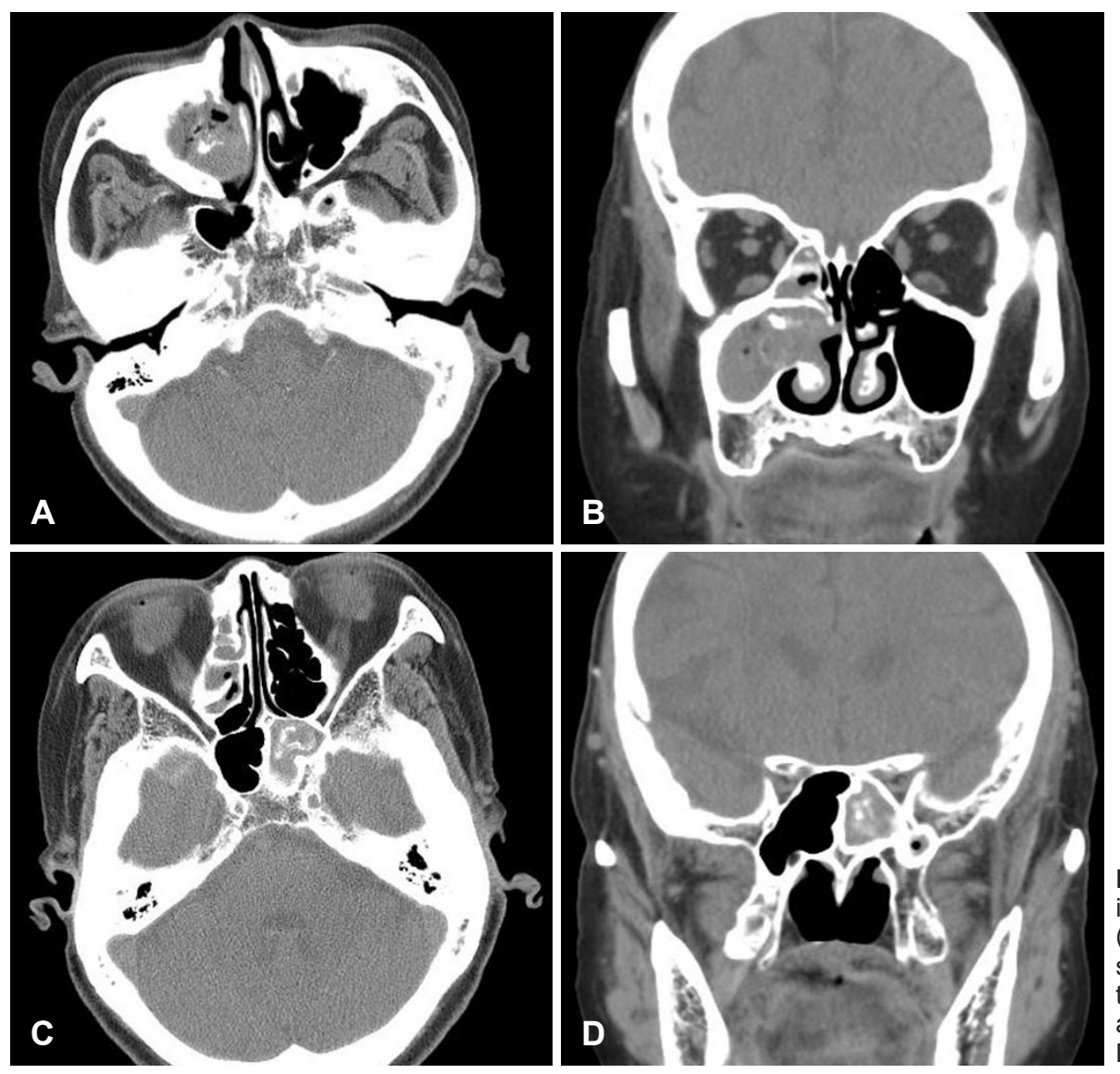

Fig. 3. Preoperative CT scans. Axial image (A and $\mathrm{C}$ ) and coronal image $(B$ and $D)$ show microcalcifications, soft tissue density and bony sinus wall thickening in right maxillary sinus ( $A$ and $B$ ) and left sphenoid sinus ( $C$ and D).

자, 당뇨 등 대사장애질환 뿐만 아니라 후천성면역결핍증 같은 질환의 빈도가 점점 증가하기 때문이다.

진균구는 진균성 부비동염 중 가장 흔히 접하게 되는 질환 으로 비특이적인 증상을 보이고, 비강내시경 상에서 정상적인 소견이 관찰되는 일이 많다. 진균구는 대다수 편측성으로 단 일 부비동에서 발견되지만, 드물게는 양측 부비동 두 군데 이 상을 침범하는 증례가 보고되어 있다.,6) 이와 관련된 연구를 보면 Klossek 등1)은 109명의 진균구 환자 중 양측 상악동에 발생한 진균구는 2 명(1.8\%)이었고, Lee 등 ${ }^{2}$ 은 245명의 진균구 환자 중에서 8 명이 양측성(3.2\%)이었음을 후향적으로 확인하 였다. Nicolai 등 ${ }^{3}$ 과 Ferreiro 등 ${ }^{4}$ 은 각각 160 명 중 2명(1.25\%) 이, 29 명 중 1 명(3.4\%)이 양측성으로 발생한 진균구를 보고하 였다.

진균구의 유발인자로는 비중격 만곡증, 역중비갑개, 부비동 개구 복합체의 폐쇄 등 국소적인 해부학적 이상이 거론되고 있으나, 부비동 입구의 폐쇄와 이에 따른 부비동내 점액섬모기 능의 장애로 인한 부비동 환기장애가 유일한 위험인자로 추정 되고 있다. ${ }^{7)}$ 진균이 부비동 내로 들어가더라도 부비동의 개구 부가 열려있고 점액섬모기능이 정상이라면 자연적으로 진균이 배출되어 병변이 발생하지 않지만, 부비동으로 흡입된 진균에
의한 점막의 염증반응은 부비동 자연개구부를 막아 산소분압 을 떨어뜨려 진균이 성장할 수 있는 최적의 조건을 만들게 된 다. ${ }^{7)}$ 하지만, 최근 Tsai 등이이 부비동 입구의 폐쇄가 상악동 진 균구의 발생과 연관성이 없다고 보고하기도 하여, 진균구가 발 생하는 기전에 대해서는 아직까지 논란의 여지가 많은 실정이 다. 특히 양측으로 생긴 경우는 더 드물기 때문에 진균구 발생 기전은 명확히 밝혀진 것은 없다. 본 증례 1 의 경우, 환자가 기 저질환으로 갖고 있던 갑상선기능저하증과 관련되어 비강점 막의 부종, 울혈 등 ${ }^{9}$ 이 부비동 자연개구부를 막았을 가능성 을 생각해 볼 수 있다.

본 증례의 경우 양측성으로 진균구가 발생했다고 해서 일 측성 진균구와 비교하여 특별히 임상증상이 다르지는 않았 다. 일측성 진균구의 임상증상으로는 대개 만성 부비동염과 비슷하게 코막힘, 화농성 비루, 후각 이상, 안면부 통증 등을 나타낸다. 드물게 경련, 비출혈, 안구돌출 등과 같은 증상을 나 타내기도 한다. ${ }^{7)}$ Klossek 등 ${ }^{1}$ 은 코막힘이 가장 흔한 증상이 라고 보고하였고, Robey 등이은 진균구의 가장 흔한 증상 3 가 지를 두통, 코막힘 그리고 점액분비라고 정리하였다. Klossek 등 $^{1)}$ 의 보고에 따르면 환자의 $18 \%$ 에서 증상이 없었고, $52 \%$ 에 서 정상적인 내시경 소견을 보였다고 보고하였다. 다만 $\mathrm{Gau}$ 등 

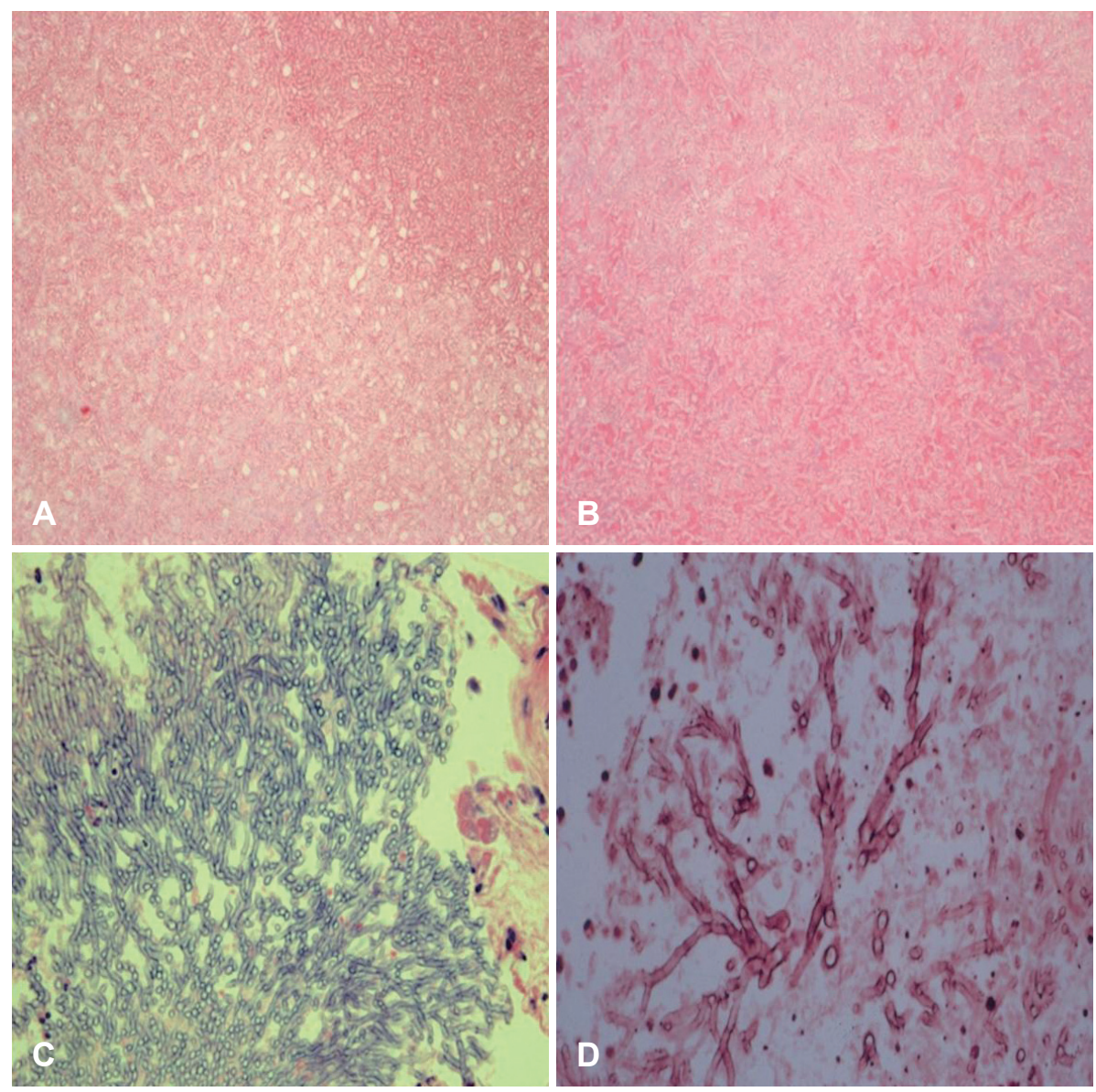

Fig. 4. Fungus ball was observed in right maxillary sinus (H\&E stain, $\times 100$ ) (A) and left sphenoid sinus ( $H$ \&E stain, $\times 100$ )(B). Branching, septate hyphae are close-packed here. Histologic sections from this case show septate hyphae with acute-angle branching, features consistent with Aspergillus (GMS stain, $\times 200)(C)$. The hyphae of fungus ball show septate filaments, regular thick, branching at acute angle (Silver stain, $\times 400)(D)$.

은 양측 부비동에 진균구(aspergillosis)와 골수외성 형질세포 종(extramedullary plasmacytoma)이 함께 존재하였음을 보 고하였다. 따라서 양측성으로 발생한 진균성 부비동염의 경우 함께 이환되어 있는 암과 같은 다른 질환이 있을 수 있음을 간 과해서는 안된다.

컴퓨터단층촬영은 부비동의 병변을 확인하기에 가장 중요 한 검사이다. 진균구는 컴퓨터단층촬영 상 33 64\%에서 석회 화 소견이 병변 내에서 관찰되어 진단에 도움을 준다. ${ }^{12)}$ 컴퓨 터단층촬영으로 골의 해부학이나 미세한 골미란 및 골파괴 소 견을 잘 관찰할 수 있다. 자기공명영상촬영은 컴퓨터단층촬영 보다 연조직 병변을 보기에 훨씬 유용하고 정확하다. 골파괴 소견은 국균 감염과 악성종양 모두에서 흔히 볼 수 있는 소견 이다. ${ }^{13)}$ 따라서 컴퓨터단층촬영 상에서 부비동에 진균구와 골 미란 소견이 관찰되면 자기공명영상촬영은 함께 존재할 수 있 는 악성종양의 가능성을 배제하기 위해 고려될 수 있다. 자기 공명영상으로 부비동의 점막 비후와 중심에 자리잡은 진균구 를 잘 확인할 수 있을 뿐만 아니라 자기공명영상은 악성종양 으로 인한 점막비후를 감별하는 데 도움을 준다. ${ }^{11}$

진균구의 치료 원칙은 수술적 완전제거 및 비강 내로 충분
한 환기가 이루어질 수 있게 만드는 것이 필수이다. ${ }^{13)}$ 상악동의 진균구는 대개 중비도개창술을 크게 열고 굽은 흡인관을 이 용해서 제거할 수 있는데, 잔존 진균구의 완전 제거를 위해서 많이 알려진 malleable suction의 사용과 생리식염수 세척 (saline irrigation)이 있으며, 거즈를 이용한 기술(gauze-assisted technique), ${ }^{14)}$ 상악동 중비도 개방술과 상악동 하비도 개방술을 동시(combined middle and inferior meatal antrostomy)에 시행하는 방법 ${ }^{15)}$ 도 보고되어 있다. 저자들은 부비 동 진균구의 완전제거를 위해서 생리식염수 세척(saline irrigation)을 시행하고 malleable suction을 이용하였다. 진균구 는 특이적인 증상이 없으므로 진단은 우선 의심을 하는 것이 중요하다. 장기간의 약물치료에도 잘 반응을 보이지 않는 양 측성 부비동염인 경우 드물지만 양측 진균구에 의한 부비동 가능성이 있으므로 부비동 컴퓨터단층촬영 및 자기공명촬영 을 통한 감별진단 및 치료가 필요하다. 또한 매우 드물지만 양 측성 부비동 진균구의 경우 잠재적으로 악성종양과 동반된 경 우도 있으므로 주의하여야 한다. 이 경우에는 치료 계획 및 방 향이 달라지므로 임상의는 항상 염두에 두고 접근을 하는 것 도 필요하다. 


\section{REFERENCES}

1) Klossek JM, Serrano E, Péloquin L, Percodani J, Fontanel JP, Pessey JJ. Functional endoscopic sinus surgery and 109 mycetomas of paranasal sinuses. Laryngoscope 1997;107(1):112-7.

2) Lee DH, Joo YE, Lim SC. Fungus balls of the bilateral paranasal sinuses. Indian J Otolaryngol Head Neck Surg 2013;65(Suppl 2): 320-3.

3) Nicolai P, Lombardi D, Tomenzoli D, Villaret AB, Piccioni M, Mensi M, et al. Fungus ball of the paranasal sinuses: experience in 160 patients treated with endoscopic surgery. Laryngoscope 2009;119 (11):2275-9.

4) Ferreiro JA, Carlson BA, Cody DT 3rd. Paranasal sinus fungus balls. Head Neck 1997;19(6):481-6.

5) Donald PJ. Fungal infections of the sinuses. In: Donald PJ, Gluckman JL, Rice DH, editors. The Sinuses. New York: Raven Press;1995. p. 271-86.

6) Chao TK. Triple discrete fungus balls of the paranasal sinuses. Otolaryngol Head Neck Surg 2004;131(6):1014-5.

7) Cho IK, Chung YJ. A case of multiple discrete fungus balls of the bilateral paranasal sinuses. Korean J Otorhinolaryngol-Head Neck Surg 2009;52(5):457-60.

8) Tsai TL, Guo YC, Ho CY, Lin CZ. The role of ostiomeatal complex obstruction in maxillary fungus ball. Otolaryngol Head Neck Surg
2006;134(3):494-8.

9) Shah R, McGrath KG. Chapter 6: Nonallergic rhinitis. Allergy Asthma Proc 2012;33 Suppl 1:S19-21.

10) Robey AB, O'Brien EK, Richardson BE, Baker JJ, Poage DP, Leopold DA. The changing face of paranasal sinus fungus balls. Ann Otol Rhinol Laryngol 2009;118(7):500-5.

11) Gau JS, Lu NH, Yeh LR, HsuTY, Wu HB, Yeh SA, et al. Coexistence of extramedullary plasmacytoma and fungus balls in the paranasal sinuses: report a case. J Med Cases 2011;2(4):162-5.

12) Kim SW, Park YJ, Kim SW, Kang MG, Joo YH, Cho JH. A clinical analysis of fungal sinusitis. Korean J Otolaryngol-Head Neck Surg 2005;48(3):332-7.

13) Dufour X, Kauffmann-Lacroix C, Ferrie JC, Goujon JM, Rodier MH, Klossek JM. Paranasal sinus fungus ball: epidemiology, clinical features and diagnosis. A retrospective analysis of 173 cases from a single medical center in France, 1989-2002. Med Mycol 2006;44(1): 61-7.

14) Chao TK, Liu CM. Gauze-assisted technique in endoscopic removal of fungus balls of the maxillary sinus. Am J Rhinol 2006;20(4):417-20.

15) Chobillon MA, Jankowski R. What are the advantages of the endoscopic canine fossa approach in treating maxillary sinus aspergillomas? Rhinology 2004;42(4):230-5. 